\title{
Milk Nuggets: A Rich Source of Vegetarian Protein
}

\author{
Durga Devi, Basant Bais*, Lokesh Tak, Parma Ram Gorachiya and Sanjay Singh \\ Department of Livestock Products Technology, India
}

Submission: September 27, 2017; Published: October 31, 2017

*Corresponding author: Basant Bais, Professor and Head, Department of Livestock Products Technology, College of Veterinary and Animal Science, RAJUVAS, Bikaner, India, Email: basantbais@gmail.com

\begin{abstract}
Majority of Indian population is lacto-vegetarian who consumes food from vegetarian origin except the milk and milk products. The protein requirement of a large population is met from plant sources. Protein deficiency, particularly animal protein deficiency is the most common nutritional deficiency observed in India. The per capita protein availability in India is 58g/day of which animal protein is only $9.5 \mathrm{~g}$ against world average of $25 \mathrm{~g}$. In view of low consumption of animal source based protein by the Indian population, the supply of milk protein as a source of animal protein in the form of nuggets has a great potential to fulfill the animal protein deficiency in the diet. Nuggets from milk protein can be effectively used as replacer of meat or animal protein.
\end{abstract}

\section{Introduction}

Protein rich vegetable origin foods like soy nuggets are becoming increasingly popular in the market. A variety of branded and unbranded nuggets are available locally. These are generally texturized vegetable proteins (TVP) with a fine fiber structure, made from defatted soybean meal. The soy nuggets with their good hydration properties can be used in a wide range of food preparations. These soy nuggets, in spite of having textural and mouth feel characteristics like lean meat cannot be considered as a substitute for animal products like meat or milk. Soy proteins are also reported to cause allergy in some people, contain anti-nutritional factors (trypsin inhibitor), and lacks in vital sulfur containing amino acids, and hence does not allow it to be included in GRAS (Generally Recognized as Safe) foods. Under such situation, nuggets from milk protein can be effectively used as replacer of meat or animal protein.

Milk contains approximately $3.5 \%$ protein and it is exceptionally high quality. They are still considered the nutritionally best valued food proteins due to their content of essential amino acids and a high digestibility. Certainly flavor and nutritional quality are superior to those of soy protein. Texturization is a process where restructuring of protein is taking place. In dairy industry, cheese is a basic, very long established example of a textured protein and rennet casein plastics too. However, in case of nuggets preparation, protein texturization takes places in mechanical process in presences of heat and pressure, which sometimes improves the digestibility of the protein. Nuggets are small cube shaped convenience product. Nuggets prepared from meat are commonly available and has very good consumer acceptability. Various research studies have been conducted on meat nuggets from chicken [1,2], pork [3], buffalo meat [4,5], mutton [4,6] chevron and rabbit meat [7] and fish. An attempt has been made by Jain [7] and Mohapatra [8] to prepare milk nuggets Nuggets from milk protein may also give an alternative.

Nuggets from milk protein can be effectively used as replacer of meat or animal protein

- In India, most of the processed milk products are traditional products.

- $\quad$ Processed milk products offer multiple benefits to consumers and producers in terms of nutrition and livelihood.

- Product diversification is the key for long term sustainability of food sector like any sector and it caters the changing need of market.

- Diversification of product base can be improved with adding more functionality in food development endeavor

- $\quad$ Functionality in foods may be noted to as enhancing natural antioxidants and dietary fibers and reducing the fat, sodium and sugar level.

- Many foods of plant origin like cereals, millets, vegetables, fruits, oilseeds and fruits have been reported to contain a range of biologically active phytochemicals like polyphenols, carotenoids, omega-3-fatty acids and resistant starch 
Further, these are rich source of dietary fiber, minerals, vitamins and antioxidant so utilize milk protein for culinary preparation. There is no such milk based texturized foods similar to the soy nuggets available in the market. In order to develop this type of product, the present investigation is initiated. The advantages of developing this type of product are:

1. A new range of product in dairy diversification.

2. Value addition as a supplement of protein.

3. Longer shelf life.

4. Ready-to-Cook convenience food.

\section{Use of binders}

Processed cereal flours are being used as binders in several products. The flour is made from cereal grains such as soybean, corn, wheat, rice, rye, oat, barley, ragi, sorghum, bajra, etc use as a binder in nuggets preparation. These are the ingredients which are used as fillers, emulsifiers, stabilizer and are usually added in product formulations to improve the cooking yield, slicing characteristics, flavor, fat binding, water binding and to enhance the protein content

\section{Preservatives}

Preservatives are the additives used in raw or processed foods to improve its flavor, aroma and to reduce the microbial load. These are natural viz. spices and condiments which are used mainly for seasoning and chemical viz. salt, phosphates nitrite, sugar, etc which are also curing agents hence, helps to improve functional and keeping quality of products

\section{Spices and condiments}

Since long, spices and condiments have been widely consumed in the human diet not only as flavoring substances but also as an antimicrobial agent. Natural spices and condiments such as cinnamon leaves, red chili, turmeric, black pepper, cloves, onion, garlic and ginger have been known for exhibition of antioxidant properties $[9,10]$.

\section{References}

1. Huffman DL, Stanley MH, Cordray JC (1984) Frozen storage stability of chicken nuggets as affected by phosphates. Poult Sci 63 suppl. 1: 19-20.

2. Kondaiah N, Anjaneyulu ASR, Lakshmanan V (1993) Incorporation of chicken by-products in mutton nuggets. J of food Sci and technomysore, 30(2), 143-144.

3. Berry BW (1994) Properties of Low-Fat, Non-breaded Pork Nuggets with Added Gums and Modified Starches. J of food Sci 59(4): 742-746.

4. Sahoo J, Anjaneyulu AS (1997) Effect of natural antioxidants and vacuum packaging on the quality of buffalo meat nuggets during refrigerated storage. Meat Sci 47(3-4): 223-230.

5. Das AK, Anjaneyulu AS, Gadekar YP, Singh RP, Pragati H (2008) Effect of full-fat soy paste and textured soy granules on quality and shelf-life of goat meat nuggets in frozen storage. Meat Sci 80(3): 607-614.

6. Das DP, Kumar S, Kumar A (2015) Effects of Incorporation of Refined Vegetable Oil and Vege-Salt on Quality Characteristics of Milk Nugget: A Novel Dairy Product. Indian Vet J 92(4): 11-15.

7. Jain G (2003) Studies on processing and evaluation of milk nuggets. Izatnagar (UP) Doctoral dissertation, M. Sc. Thesis, Division of LPT, Indian Veterinary Research Institute, India.

8. Mohapatra S (2013) Development and quality evaluation of diet milk nuggets. M.Sc. Thesis, IVRI, Izatnagar, India.

9. Lee YB, Kim YS, Ashmore CRC (1986) Anti oxidative property of ginger rhizome and its application to meat products. J Food Sci 51: 20-23.

10. Dushyanthan K, Babu RN, Vasanthi C, Venkataramanujam V (2008) Processing of buffalo meat nuggets utilizing different binders. Tamilnadu J Veterinary \& Animal Sciences 4(2): 77-83.

Your next submission with Juniper Publishers will reach you the below assets

- Quality Editorial service

- Swift Peer Review

- Reprints availability

- E-prints Service

- Manuscript Podcast for convenient understanding

- Global attainment for your research

- Manuscript accessibility in different formats

( Pdf, E-pub, Full Text, Audio)

- Unceasing customer service

Track the below URL for one-step submission https://juniperpublishers.com/online-submission.php 